\title{
Unequal struggle in South Africa
}

SIR - I should like to comment on your leading article and on the opening story in the Briefing by Michael Cherry on South African science (Nature 384, 1 \& 11-15; 1996). Your leading article rightly recognizes the need for reforms to "redress the idiosyncrasies" of the previous government and that the published policies look good on paper. In the second article, Cherry points out that the published policies have raised the hopes of many South African scientists, yet are slow in taking effect and are likely to be constrained in their effectiveness. Both articles give a good representation of the state of South African science and neither is shy of direct criticism.

Cherry draws attention to the fact that achieving the anticipated "renaissance", which many South African scientists, in his opinion, perceive to be "just around the corner", is likely to be constrained by political and financial factors. I agree, but I should like to expand on the political constraints by drawing attention to an overriding policy not mentioned in the articles, namely "affirmative action".

Unlike Cherry, who I gather is an established academic at one of the five 'major' universities in South Africa (which are all historically white universities, of course), I am a PhD student. I also happen to be at an historically black university, where I have been temporarily employed as a researcher for 6.5 years. As I am nearing completion of my $\mathrm{PhD}$, I am seeking to establish myself as an academic so as to contribute to the development of science in the new South Africa. It is in this position that I have realized the full force of affirmative action, because I am white.

Until recently, I had the optimism and high hopes that Cherry mentions, but not any more. Whereas black graduates have access to local and foreign funds, and opportunities to study abroad and get jobs, the same does not apply to their white compatriots. It is only established white South African scientists who can afford to be optimistic. Yet I hear established, worldclass South African scientists voicing their concern more and more often about the future for (white) graduates in the country.

I do not begrudge young black South African scientists the long overdue opportunities that are now available, but what happened to 'equal opportunity'? Is the ruthless application of African nationalist ideology, under the guise of affirmative action, and at the expense of local expertise, really the way to "redress the idiosyncrasies" of the previous government?

It is true that reforms are necessary and that the published policies raise the levels of hope, but it is the anticipated non-implementation and ineffectiveness of the pro- posed changes and, rather, the implementation of unpublished policies, that concerns me. The last sentence of your leading article, Sir, starts with a very big "If"!

\section{Peter F. Scogings}

Agricultural \& Rural Development

Research Institute,

University of Fort Hare,

Alice ZA-5700, South Africa

e-mail: scogings@ardri.ufh.ac.za

\section{The moral ape}

SIR - Frans de Waal's argument for emergent unselfishness in the great apes and humans is a welcome challenge to the belief that, because genes are selfish, all higher levels of biological activity are fundamentally selfish as well (Nature 383, 785; 1996). I find no conflict in accepting genelevel selfishness and neocortical-level unselfishness in complex brains.

The handful of experts in chimpanzee and bonobo social behaviour (indeed, they can be counted on one hand) all emphasize the ways in which the social behaviour of these primates shares features of human behaviour: apparent concern for community well-being, acts of caring and consolation toward non-kin as well as kin, reconciliation after fights, reciprocal sharing of resources (and retaliation for nonreciprocity) and an apparent social 'conscience'.

Because of the close genetic relationship of chimpanzees, bonobos and humans, as revealed by DNA-DNA hybridization, gene sequencing and morphology, we should seriously consider the behaviour of these close relatives as being evolutionarily relevant to ours, as de Waal urges (in Good Natured: The Origins of Right and Wrong in Humans and Other Animals; Harvard University Press, 1996). Instead of merely being appended atop a selfish core, 'moral' behaviour may have become deeply integrated by natural selection into our psychological nature. In my experience as a mental health professional and as a human being, I have observed profoundly unselfish feelings and behaviour which appear as genuine as their selfish counterparts.

\section{Gregory G. Dimijian}

University of Texas Southwestern Medical Center at Dallas,

5323 Harry Hines Boulevard,

Dallas, Texas 75235-9070, USA

e-mail: dimijian@connect.net

\section{corres@nature.com}

Letters submitted for Correspondence may be e-mailed to corres@nature.com. Do not send items intended for any other section by e-mail unless requested to do so.

\section{Postdoc woes}

SIR - I read with interest the correspondence (Nature 384, 103; 1996) about the difficulties experienced by today's young researchers. As such a person, I believe postdoctoral experience is extremely valuable to the development of one's research career, particularly if undertaken at foreign institutions where the differences in culture and methods are the most striking and can be of the most benefit.

But asking someone to make such an undertaking today is I believe, unfair. Most postdoctoral scientists receive wages above the local average, but when moving to a different country this may be far from sufficient. Some institutions still do not include travel or relocation expenses for new staff members. Foreign governments usually prohibit accompanying partners of temporary workers to seek paid employment. As most families need more than one breadwinner, the family income is effectively halved.

Not all countries provide for superannuation or retirement annuity, which is becoming increasingly important because of the down-sizing of social security. Having retirement funds, when available, in different countries is a disadvantage compared to someone with funds in only one country. And moving funds to another country incurs penalties for early withdrawal.

All these problems are exacerbated when young researchers are essentially forced to undertake more than one postdoctoral term because of the relative scarcity of more senior and stable positions. With so many researchers in the world, most of whom have jumped through the same hoops for many years, things might have been expected to have changed for the better by now. Administrators should realize that work and family conditions are different from 20 or so years ago.

We come ultimately to the question of whether obtaining a $\mathrm{PhD}$ lives up to our expectations. A PhD is always valuable, but it involves a special level of commitment and love for a particular subject. Most graduates do not complete a PhD so as to become World-Wide Web programmers.

Career and family responsibilities may always have clashed, but young researchers are now asking themselves too often whether to cut their losses and run. The way science is done today has changed and institutions should respond accordingly, for their own sakes and for the sakes of the researchers who support them.

\section{Emanuel Vassiliadis}

Instituto de Astrofisica de Canarias (IAC), c/- Via Lactea $S / N$,

E-38200 La Laguna, Tenerife,

Canary Islands, Spain

email: vass@iac.es 